\title{
THE EFFECT OF EPINEPHRINE ON ANAESTHETIZED HYPERTHYROID DOGS PRETREATED WITH RESERPINE AND/OR GUANETHIDINE
}

\author{
Peter Kwang-yi Lee, m D $\nmid$ Jacob S Israed, m D, and Allen B Dobxin, M D
}

THERE Is a contmuing search to find new and safer drugs to restore normal metabolism to the hyperthyroid patient and to protect the euthyroid patient from the stress of noxious stimuli to the cardiovascular system Spontaneous cardiac arrhythmias are sometımes observed during anaesthesıa in euthyroid patients, but they can occur far more frequently either in the undiagnosed or in the frankly hyperthyroid individual ${ }^{12}$ Studies in hyperthyroid dogs have substantiated these clinical impressions ${ }^{4}$

Reserpine and guanethidine have been used in the treatment of hyperthyroid patients to relieve some of their distressing symptoms ${ }^{5,6}$ The beneficial action of both of these drugs in hyperthyroid individuals probably results from depletion of body epinephrine stores 78

Even though reserpine and guanethidine are valuable in the treatment of patients with various diseases, ${ }^{569} 10$ they have been implicated às a direct cause of morbidity during anaesthesia and surgery Terminating their use a few days before administration of anaesthesia has therefore been suggested ${ }^{11} 12$

This study was undertaken to determine whether or not the response of anaesthetized hyperthyroid dogs to a standard epinephrine challenge was altered by pretreatment with reserpine, guanethidine, or a combination of both drugs

\section{METHOD}

Three groups of experiments were planned on each of 10 medium-sized (15$20 \mathrm{~kg}$ ) mongrel dogs The dogs were weighed and blood for thyroxine-1odine $\left(\mathrm{T}_{4}\right)$ by column determinations was drawn from the 10 dogs in the fasting state ${ }^{13}$ Once daly, they were hand-fed Protamone (1odmated casem with 1 per cent free 1odine and 7 per cent protein-bound 1odine) in gelatm capsules wrapped in meat The dose of Protamone given was $03 \mathrm{gm} /$ day for 6 days, $09 \mathrm{gm} /$ day for 5 days, and $18 \mathrm{gm} /$ day for a period of 10 days After 21 days of therapy, blood for $T_{4}$ by column tests was drawn from these dogs

\section{Group I}

Five of the 10 dogs were then given $75 \mathrm{mg} / \mathrm{kg}$ of guanethidine intravenously twice, three hours apart On the following day, the dogs were weighed in the fasting state (mean $178 \mathrm{~kg}$ ) and then anaesthetized with a sleep dose of tho-

\footnotetext{
From the Department of Anesthesiology, Sitate University of New York, Upstate Medical Center, Syracuse, New York

Postdoctoral Research Fellow
} 
pental and $20 \mathrm{mg}$ of succinylcholine chlonde was used to facilitate intubation. An infusion of isotonic saline was started at this time to maintain hydration and provide a route for the injection of the epmephrine challenge Breathing was augmented, with a Takaoka respirator for the maintenance of adequate pulmonary ventilation ${ }^{14}$ The volume of ventilation was set so that the animal would receive a minute volume of $400 \mathrm{ml} / \mathrm{kg}$ body weight Immediately following endotracheal intubation, an electrocardiogram (lead 2) was recorded on each dog while the animal was being ventilated with 100 per cent oxygen Following the control tracing, 10 to 15 per cent methoxyflurane was volatilized with oxygen and administered to the dog from a calibrated tempes ature-compensated vaporizer (Pentec ${ }^{\circledR}$ ) At 5-minute intervals, an electrocardıogram tracing was taken until 25 minutes of methoxyflurane anaesthesia had elapsed Then, an intravenous challenge with $002 \mathrm{mg}$ of epinephrine $/ \mathrm{kg}$ body weight was administered in a solution containing $002 \mathrm{mg} / \mathrm{ml}$, injected at the rate of $1 \mathrm{ml} / \mathrm{sec}$ The electrocardiogram tracing was recorded continuously until it returned to the pre-injection configuration or the dog died of ventricular fibrillation Because four of the five dogs in Group I died, no further animals were studied in that group

\section{Group II}

Four of the initial 10 dogs were continued on Protamone $180 \mathrm{gm} /$ day and, in addition, were hand-fed reserpine $35 \mathrm{gamma} / \mathrm{kg} /$ day for a subsequent period of 14 days These dogs were then weighed (mean $1775 \mathrm{~kg}$ ), anaesthetzzed, and challenged with epmephrme as described above Because all four of the anmals studied in this group died, no further animals were studied

\section{Group III}

One survivor of Group I, and nine fresh dogs pretreated with Protamone for 21 days, were continued on Protamone and reserpine as described for Group II On the day before the experıment, they were also given guanethidine $15 \mathrm{mg} / \mathrm{kg}$ in divided doses as described for Group I The next day, they were weighed (mean $166 \mathrm{~kg}$ ), anaesthetized, and challenged with epinephrine as described above

\section{RESULTS}

The type, incidence, and duration of cardiac arrhythmias that occurred after epinephrine challenge are summarized in Tables I and II

The level of thyroxine odine for the euthyroid dogs ranged from 09 to 30 $\mu \mathrm{g}$ per cent with a mean of $17 \mu \mathrm{g}$ per cent After 21 days of Protamone therapy, the thyroxine sodine determinations 1 anged from 42 to $87 \mu \mathrm{g}$ per cent with a mean of $64 \mu \mathrm{g}$ per cent

On the day the experiments were performed, there was a 5 per cent, 12 per cent, and 5 per cent reduction in body weight of the hyperthyroid dogs in Group I, II, and III, respectively, from their control values 

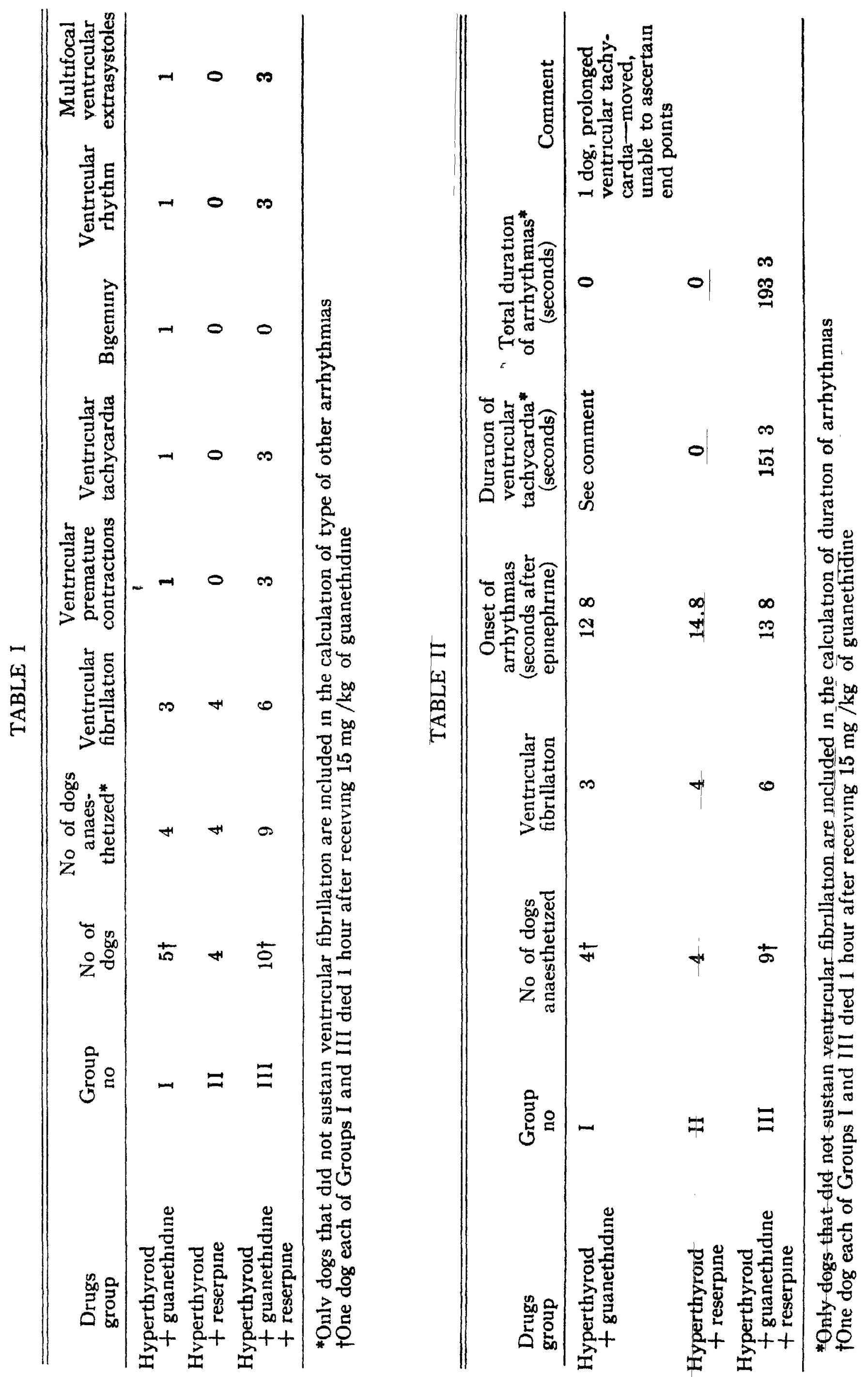
The mean heart rate after endotracheal intubation for Group I dogs was 105 beats/minute, for Group II, 133 beats/minute, and for Group III, 107 beats/ minute After 25 minutes of anaesthesia with methoxyflurane, the heart rate decreased at least 25 per cent in all groups For Group I, the mean heart rate was then 65 beats/minute, Group II, 59 beats/minute, and Group III, 80 beats/ minute One dog in Group I and one dog in Group III died shortly after receiving a tolal of $15 \mathrm{mg}$ guanethidine

After the epinephrine challenge, the following electrocardiographic changes were seen All of the hyperthyroid dogs developed either ventricular tachycardia or ventricular fibrillation Three of four dogs (Group I) pretreated with guanethidine, four of four dogs (Group II) pretreated with reserpine, and sx of nine dogs (Group III) pretreated with reserpine and guanethidine developed ventricular fibrillation

The one surviving dog of Group I (hyperthyroid, guanethidine pretreatment) had a long period of ventricular tachycardia The three surviving dogs of Group III (reserpine and guanethidine pretreatment, hyperthyroid dogs) sustained severe and prolonged ventricular tachycardias lasting an average of 1513 seconds In Group III, the mean duration of arrhythmias in the surviving dogs, after the epinephrine challenge, was 1933 seconds

\section{Discussion}

The normal range for thyroxine $\left(\mathbb{T}_{4}\right)$ by column method, utilizing the anionexchange resin Dowex-1, is 32 to $64 \mu \mathrm{g}$ per cent in human controls, $1 \mathrm{e}$, the same as for the butanol-extractable lodine method ${ }^{13}$ In this study, the control value for 10 dogs was $17 \mu \mathrm{g}$ per cent, with a range of 09 to $30 \mu \mathrm{g}$ per cent From a previous study, ${ }^{4}$ we observe that the PBI determinations in the control dogs were lower than normal human controls $T$ The $\mathbf{T}_{4}$ by column controls indrcated a similar relationship between the human and dog values In the hyperthyroid state, all of the determmations were higher than the corresponding control with the $\mathbb{T}_{4}$ by column, averaging $64 \mu \mathrm{g}$ per cent $F$ urther, $T_{4}$ by column determinations were discontinued because the results of the tests gave an inadequate estimation owing to incomplete separation of some of the organic constituents ${ }^{15}$

In the original plan of this study, Groups I, II, and III were to have contaned 10 dogs each When the high mortality was seen-four deaths out of the five dogs in Group I and four deaths of the four dogs in Group II-the effect was clear, so it was decided not to sacrifice the animals unnecessarily It was obvious that carrying out the planned number of experiments would contribute little to the observation that guanethidine or reserpine in hyperthyroid dogs does not protect against epinephrine-induced arrhythmias

In a previous study, ${ }^{4}$ it was seen that there is an increased incidence and severity of unduced. arrhythmias in anaesthetzzed hyperthyroid dogs It appear; that in the hyperthyroid state there is no demonstrable increase in epinephrine entering the bloodstream from the adrenal glands ${ }^{16}$ Instead, there appears to be an increase in sensitivity to $1 \mathrm{it}^{17}$ and a prolongation of epinephrine action, possibly 
on the basis of decreased oxidation|related to a decrease in curculating amine oxidase ${ }^{18,19}$

The base-line heart rate of dogs in Groups I, II, and II was slower than that of comparable dogs not pretreated with guanethidine and/or reserpine 4 After 25 minutes of methoxyflurane anaesthesia, the heart rate of all of these dogs decreased even further This was evidently due to the negative chronotropic effect of guanethidine and reserpine, ${ }^{7,8}$ augmenting a similar effect of methoxyflurane on hyperthyroid dogs 4

Reserpine pretreatment causes catecholarnme depletion and the resulting sympathetic depression is undoubtedly only one of the many variables which may affect the curculatory status of a patient who is to undergo anaesthesia. It seems, therefore, that it would be more useful to evaluate the situation as a whole, rather than to focus attention on reserpine medication alone. ${ }^{8}$ Recently, Alper and associates stated further that lowering the blood pressure with reserpine might decrease the anaesthetic risk in some patients ${ }^{8}$

When dogs are pietreated with guanethidine and/or reserpine, they appear to have an increased sensitivity of the heart and blood vessels to catecholamines ${ }^{20-24}$ The reason for this supersensitivity is not completely understood. ${ }^{23}$ Fleming and Trendelenburg have shown that supersensitıvity becomes progressively greater with increasing length of reserpine therapy ${ }^{21}$ They also demonstrated that development of supersensitivity requires time following depletion and that it results from inactivity of the effector organ ${ }^{23}$ irrespective of whether such inactivity is the consequence of denervation, of loss of transmitter caused by reserpine, or of the administiation of cocame ${ }^{8}$ The mechanısms for guanethidine supersensitivity may very well be the same, although recent views of Brodie suggest that these two drugs have different modes of action ${ }^{25}$ Thus, it would appear to be extremely dangerous to administer epmephrme to hyperthyroid patients, especially if they are receiving guanethidine and/or reserpine concurrently

\section{SUMMARY AND CONCLUSIONS}

Dogs made hyperthyroid with Protamone were anaesthetized with thiopentone and methoxyflurane after pretreatment with either guanethidine and/or reserpine They were then given a standard epinephrine challenge Ventricular fibrillation and other severe ventricular arrhythmias were seen more frequently in all of these anumals than was observed in previous studies of hyperthyroid dogs anaesthetized with methoxyflurane, but not pretreated with reserpine and/or guanethidine

Thus, by mference from the literature reviewed and the expernmental work of this paper, it would appear to be extremely dangerous to administer epinephrine to hyperthyroid patients while they are receiving guanethidine and/or reserpine therapy

\section{ACKNOWLEDGMENT}

This study was supported by grants-in-aid from Ciba Pharmaceutical Company, Summit, New Jersey, and from Abbott Laboratories, Chicago, Illinois 


\section{RÉSUMÉ}

Après avoir traité à la guanethıdıne et/ou à la réserpıne des chıens rendus hyperthyroidiens par la Protamone, nous les avons anesthésıés au thiopentone el au méthoxyflurane Nous avons fait alors sur ces chien', une épreuve standard à l'épınéphıne Chez tous ces anımaux, nous avons observé des fibrillations ventri† cularres et d'autres arythmies graves plus fréquemment que nous ne l'avions fart, au cours d'études antérieures, chez des chiens hyperthyroıdiens anesthésiés aư méthoxyflurane, mais non traités au préalable à la réserpine et/ou à la guanethidine

En conséquence, d'après les publicatıons antérieures et le travall expérimental rapporté dans cet artıcle, ıl semble très dangereux de donner de l'épınéphrıne à des hyperthyroıdiens qui reçoıvent de la guanethıdıne et/ou de la réserpıne

\section{REFERENCES}

1 Delit, C, Silver, S, Yohalem, S B, \& Segal, R L Thyrocardiac Disease and Its Management With Radioactive Iodme (I181) J A M A 176262 (1961)

2 Hoffman, I, \& Lowery, R D The Electrocardiogram in Thyrotoxacosis Am J Cardiol 6893 (1960)

3 Hudson, R H Toxic Goitre and Abnormal Cardiac Rhythm. Proc Roy Soc Med 52810 (1959)

4 Israei, J S, Byles, P H, \& DoBkin, A B The Cardiac Effect of Epinephrine during Anaesthesia in Hyperthyro1d Dogs Canad Anaesth Soc J 9437 (1962)

5 Canary, J J, SchaAf, M, DuFfy, B J, JR, \& KYLE, L H Effects of Oral and Intramuscular Administration of Reserpine in Thyrotoxacosis New Engl J Med 257435 (1957)

6 Gaffiney, T E, Braunwaid, E, \& Kahler, R L Eflects of Guanethidune on Tin Iodothyronine-Induced Hyperthyroidism in Man New Engl J Med 26516 (1961)

7 GaffNex, T E, Braunwald, E, \& Cooper, T Analysis of the Acute Circulatory Effects of Guanethidine and Bretylum Circ Res 1083 (1962)

8 Alper, M H , FLACKE, W, \& KrAYER, O Pharmacology of Reserpine and Its Implicationis for Anesthesia Anesthesiology 24524 (1963)

9 Merrill, J P Diagnosis and Treatment of Renal Hypertension of Humoral Ongan Anesthesiology $24 \quad 479$ (1963)

10 Lewis, J A, \& Kavelman, D A Long-term Follow-up of Patients with Hypertensive Disease Treated with Guanethidine Canad Med Assoc J 38 1010 (1963)

11 ZIEGLER, C H, \& LovetTe, J B Operative Complications after Therapy with Reserpine and Reserpine Compounds J A M A I76 916 (1961)

12 Crandall, $D, L$ The Anesthetic Hazards in Patients on Ant1-hypertensive Therapy J A M A 179495 (1962)

13 Pileggi, V J, Lee, N D, Golub, O J, \& Henry, $R$ J Determination of Iodine Compounds in Serum I Serum Thyroxine in the Presence of Some Iodine Contaminants J Clin Endocrinol \& Metab 211272 (1961)

14. DoBkIn, A B The Takaoka Respirator for Automatic Ventilation of the Lungs Canad Anaesth Soc J 8556 (1961)

15 Personal Communication from Dr V J Pleggı (May 14, 1963)

16 Rogof,$J \mathbf{M}$, \& Conteli, $\mathbb{R}$ Epinephrine Output from the Adrenal Glands in Experimental Hyperthyroidısm J Lab \& Clin Med 26981 (1941)

17 Murray, J F, \& KELLY, J J, JR The Relation of Thyroidal Hormone Level to Epinephrine Response A Dragnostic Test for Hyperthyrondism Ann Int Med 51309 (1959)

18 Swanson, $H \quad E$ Interrelations between Thyroxin and Adrenalin in the Regulation of Oxygen Consumption in the Albino Rat Endocrinology 59216 (1956)

19 SpINKs, A, \& Burn, J H Thyroid Activity and Amine Oxidase in the Liver Brit J Pharmacol 793 (1952) 
20. Fleming, W. W. Supersensituvity of the Cat Heart to Catecholamine-Induced Arrhythmias Following Reserpme Pretreatment Proc. Soc Exptl Biol Med 111484 (1962)

21 Burn, J H \& RAND, M J The Action of Sympathomimetic Amines in Anmmals Treated with Reserpine J Physiology 144314 (1958)

22 Flemang, W W, \& Trendelenburg, U. The Development of Supersensitivity to Norepinephrine after Pretreatment with Reserpine J Pharmacol \& Exper Therap 133. 41 (1961)

23. Krayer, O, AlPer, M H, \& PaAsonen, M $\mathbb{R}$ Action of Guanethidine and Reserpme upon the Isolated Mammalian Heart. J Pharmacol \& Exper Therap 135164 (1962).

24 Smulyan, $H$, Marizason, C $R$, Kmamley, J F, Cuddy, $R \mathbf{P}$, Eich, $R \mathbf{H}$, \& Lyons, R H Effects of Reserpine on the Circulation and on the Circulatory Responses to Tiltung and Norepinephrine Am J Cardiol 11.743 (1963)

25 Brodie, B Recent Views on Mechanisms for Lowenng Sympathetuc Tone Curculation 28970 (1963) 